\title{
Adıyaman Ekolojik Koşullarında Farklı Ekim Zamanlarında Bazı Nohut (Cicer arietinum L.) Çeşitlerinin Verim ve Kalite Özelliklerinin Belirlenmesi
}

\author{
Veli Sönmez ${ }^{1}$, Ahmet Metin Kumlay ${ }^{2 *}$ \\ ${ }^{1}$ Iğdır Üniversitesi, Fen BilimleriEnstitüsü, Tarla Bitkileri Anabilim Dalı, Iğdır, Türkiye, (ORCID: 0000-0002-0577-2128), sev_kahin@ @otmail.com \\ 2* Iğdır Üniversitesi, ZiraatFakültesi, Tarla Bitkileri Bölümü, Iğdır, Türkiye (ORCID: 0000-0001-9765-8674), akumlay@ hotmail.com
}

(İlk GelişTarihi 23 Şubat 2021 ve KabulTarihi 5 Nisan 2021)

(DOI:10.31590/ejosat.885187)

ATIF/REFERENCE: Sönmez, V. \& Kumlay, A.M. (2021). Adıyaman Ekolojik Koşullarında Farklı Ekim Zamanlarında Bazı Nohut (Cicer arietinum L.) Çeşitlerinin Verim ve Kalite Özelliklerinin Belirlenmesi. Avrupa Bilim ve Teknoloji Dergisi, (23), 656-665.

$\ddot{O} \mathbf{z}$

$\mathrm{Bu}$ araştırma, farklı ekim zamanlarında bazı nohut (Cicer arietinum L.) çeşitlerinin morfolojik ve tane özelliklerini belirlemek amacıyla 2017 yılında Adıyaman ekolojik koşullarında yürütülmüştür. Çalışmada, yörede yaygın olarak ekimi yapılan yerel genotip ile Diyar-95, ILC-482 çeşitleri ve üç farklı ekim zamanı (15 Ocak, 25 Ocak ve 4 Şubat) denemeye tabi tutulmuştur. Elde edilen verilerden; çıkış sürelerinin 12.66-15.00 gün, bitki boylarının 19.90-36.10 cm, ana dal sayılarının 2.30-2.90 adet, yan dal sayılarının 8.56-8.92 adet, çiçeklenme gün sürelerinin 75-79 gün, olgunlaşma gün sürelerinin 110-130 gün, bitkide bakla sayılarının 38.7144.15 adet, bitkide bakla ağırlığının 22.13-24.88 g, dekara tane veriminin $155.40-182.60 \mathrm{~kg} \mathrm{da}^{-1}, 100$-tane ağırlığının 35.28-41.25 g, danede protein oranının \%25.60-27.80 arasında değiştiği ortaya konulmuştur. Sonuç olarak; 25 Ocak tarihindeki ekim zamanının ve çalışmada kullanılan çeşitlerin, nohutun verim ve verim bileşenleri üzerine katkısının önemli olduğu, bu nedenle Adıyaman ve çevresi için bu çeşitlerin ve ekim zamanının tavsiye edilebileceği sonucuna varılmıştır.

\section{Determination of Yield and Quality Characteristics of Some Chickpea (Cicer arietinum $\mathbf{L}$.) Genotypes at the Different Sowing Times under Adryaman Ecological Conditions}

\begin{abstract}
The research was carried out to determine the morphological and seed characteristics of some chickpea (Cicer arietinum L.) genotypes at different sowing times on Adiyaman ecological conditions, in 2017. Diyar-95, ILC-482 cultivars and local chickpea genotype with three different sowing times (January 15th, January 25th and February 4th) were used in the study. Obtained findings illustrated that days to shoot initiation 12.66-15.00, plant height 19.90-36.10 cm, the number of main (2.30-2.90) and lateral (8.568.92) branches, days to flowering (75.00-79.00) and maturation (110-130), the number (38.71-44.15) and the weight (22.13-24.88 g) of pods on plant, seed yield per decare $155.40-182.60 \mathrm{~kg} \mathrm{da}^{-1}, 100$-seed weight $35.28-41.25 \mathrm{~g}$, the ratio of protein in seed \%25.6027.80 were changed depending on genotypes and sowing times. As a result of the study, all genotypes used in the study and $25^{\text {th }}$ of January sowing time could be advised for Adiyaman province and surrounding areas.
\end{abstract}

Keywords: Chickpea, Cicer arietinum L., Sowing Time, Genotype.

*Sorumlu Yazar:akumlay@hotmail.com 


\section{Giriş}

Nohut (Cicer arietinum L.) binlerce yıldan bu yana tarımı yapılan ender bitkilerden biri olup, gen merkezi Güneydoğu Anadolu Bölgemiz olan en önemli kültür bitkilerimizdendir. Dünya'da 50'den fazla ülkede nohut üretimi yapılmakta olup, Türkiye yaklaşı olarak 395 bin ha alanda, 470 bin ton üretimi ile nohut yetiştirici ülkeler arasında dünyada önemli bir yer tutmaktadır (TUİK 2018). Dünyada üretimi yapılan nohut çeşitleri, tane büyüklüğüne ve şekline göre desi ve kabuli tipi nohut tipleri diye 2 gruba ayrılmışlardır. Desi tip nohutlar küçük ve koyu renkli bir şekle sahipken, Kabuli tip nohutlar büyük, pürüzsüz ve açık renklidir (Purushothaman ve ark., 2014). Dünya nohut üretiminin yaklaşık \%80'i desi tip nohutlardır (Karakullukçu ve Adak, 2008). Pakistan ve Güney Asya ülkelerinde Desi tip nohut yetiştirilirken Türkiye'de ağırlıklı olarak Kabuli tip nohut yetiştirilmektedir (Aydemir ve Yemencioğlu, 2013).

Ülkemizin hemen hemen tüm bölgelerinde nohut üretimi yapılmakta, üretimde önemli olan bazı hastalıkların yazlık ekimlerde görülmemesinden dolayı, verim ve verim bileşenleri ile yüksek hasat indeksi yönünden çoğunlukla yazlık ekimlerin tercih edildiği bildirilmiştir (Anlarsal ve ark., 1999). Ancak, yazlık ekimde bitkilerin kuraklık ve sicaklık stresine maruz kalmalarından dolayı verim kaybı yaşandığından, kışlık ekime uygun uzun boylu ve sanayi tip çeşitlerin sslah edilmesinin önemli olduğu (Özdemir ve Engin, 1996; Sozen ve Karadavut, 2018; Korbu ve ark., 2020) vurgulanmıştır. Son zamanlarda soğuğa ve antraknoza dayanıklı, yüksek verimli ve verimde stabil olan yeni nohut çeşitlerinin 1slah edilmesiyle, kışlık ekimlerde daha yüksek verimlerin alınması mümkün hale gelmiştir (Avelar ve ark., 2018; Elis ve ark., 2020; Yücel, 2020). Ayrıca, nohutun baklagiller içerisinde ekstrem sıcaklıklara daha iyi dayandığı (Üstün ve Gülümser, 2003; Uzun ve ark., 2012), Kasım ayının son haftasında yapılan ekimden en yüksek verim alınmasına rağmen ekim zamanının Aralık ayına doğru geciktirilmesi durumunda verimin daha da artırılabildiği (Kabir ve ark., 2009), 1 Aralık tarihinde yapılan kışlık ekime göre, 1 Kasımda yapılan ekimden daha yüksek verim alındığı (Ray ve ark., 2017) rapor edilmiştir.

Nohut yetiştiriciliğinde verim ve verim bileşenlerine etki eden çok sayıda çevresel ve genetik değişkenler bulunmaktadır. Agronomik uygulamalar arasında verimi etkileyen en önemli faktörün ekim zamanı olduğu, farklı ekim zamanlarında iklim faktörlerine bağlı olarak bitkilerdeki çiçeklenme, tohum bağlama ve verimin değişebildiği vurgulanmıştır (Kayan ve ark., 2014). Daha önce yapılan çalışmalarda, farklı tarihlerde ekilen nohut çeşitlerinin verim ve verim bileşenleri yönünden farklılıklar gösterdiği (Karasu ve ark., 1999; Partigöç ve ark., 2007; Ray ve ark., 2017), erken ve geç kalmış ekim tarihlerinin verim ve kaliteyi etkilediği (Ali ve ark., 2018; Varoğlu ve Abak, 2018) ortaya konulmuştur. Ayrıca, nohut bitkisinde ekimin gecikmesi ile bitki boyunun ve ilk bakla yüksekliğinin azaldığı (Akdağ, 1995; Erman ve Tüfenkçi, 2004) bitki başına bakla sayısının düştüğü (Sarı ve Adak, 1998; Özgün ve ark., 2003; Topalak ve Ceyhan, 2015), olgunlaşma süresinin kısaldığ 1 (Özgün ve ark., 2005), dekara tane verimlerinin düştüğü (Akdağ, 1995; Üstün ve Gülümser, 2003; Erman ve Tüfenkçi, 2004), 100-tane ağırlığı ve tanedeki protein oranının değiştiği (Topalak ve Ceyhan, 2015) rapor edilmiştir.

Yapılan çalışmalarda, ekim zamanının bakla sayısı ve verim değerlerine önemli etkisinin olduğu (Özçelik ve ark., 2001), uzun yetişme süresinin bitki boyunu, bitkide dal ve bakla sayısını, 100-tane ağırlığını ve dolayısıyla dekara verimi artırdığ 1 (Özdemir ve Karadavut, 2003), farklı ekim zamanlarının verim ve verim bileşenlerinde önemli varyasyonlar meydana getirdiği (Türk ve Koç, 2003), oluşan bu farklılıkların çeşitlere göre değiştiği (Rehman ve ark., 2015), genetik verim kapasitesine ulaşabilmek için agronomik uygulamaların yanı sıra, uygun çeşit seçimi ve ekim zamanının ayarlanması gerektiği (Sekhar ve ark., 2015), kuraklığa dayanımı çok yüksek olan nohutta az miktarda sulama yapılması halinde ürün veriminin artırılabileceği (Çıtak ve Topak, 2016) kayıt altına alınmıştır.

Sikdar ve ark. (2015) en uzun bitki boyunun $(40.69 \mathrm{~cm})$, en fazla yan dal sayısının (24 adet), en fazla bitki başına bakla sayısının (75.63 adet), maksimum 100-tane ağırlığının (14.09 g) ve en yüksek dekara tohum veriminin (193.08 kg) $20 \mathrm{Kasim}$ tarihindeki ekim tarihinden elde edildiğini rapor etmişlerdir. Buna karşın, Salih ve ark. (2018)'nın çalışmalarında en uzun bitkilerin $(43.0 \mathrm{~cm})$, en geniş yaprak alanının $\left(797.83 \mathrm{~cm}^{2}\right)$, en büyük yaprak alan indeksinin (2.66), en fazla bitkide bakla sayısının (21.60 adet) ve en fazla dekara tane veriminin $(216 \mathrm{~kg})$ 20 Ocak tarihinde yapılan ekimden elde edildiğini kayda geçmişlerdir. Türk ve Polat (2019), farklı ekim zamanlarında ekilen nohut bitkisinin iki yıllık ortalamasına göre; bitki başına 6.81-13.65 g verim, 16.77-28.56 adet bakla say1s1, 14.83-29.00 adet bitkide tane sayıs1, 0.89-1.03 adet baklada tane sayıs1, dekara $229.7-444.4 \mathrm{~kg}$ biyolojik verim, \%47.58-49.82 hasat indeksi ve 39.08-41.78 g arasında 100-tane ağırlığı elde etmişlerdir.

Bu çalışmanın amacı Adıyaman ve çevresinde yaygın olarak ekimi yapılan yerel genotip ile iki farklı kültür çeşidinin farklı kışlık ekim zamanlarında verim ve verim unsurları yönünden değerlendirmesinin yapılması ve elde edilen sonuçların yöre çiftçilerinin hizmetine sunulmasıdır.

\section{Materyal ve Metot}

\subsection{Materyal}

Araştırmada kullanılan yerel genotip ve çeşitlerin özellikleri aşağıda verilmiştir.

Yerel genotip: Tane rengi krem, tane tipi koçbaşı ve ortalama verim potansiyeli $140-180 \mathrm{~kg} \mathrm{da}^{-1}$ 'dır. Yazlık ekimde bitki boyu 40-70 cm, bakla sayısı 18-25 adet, çiçeklenme gün sayıs1 75-90, olgunlaşma gün sayısı 120-130, baklada tane sayısı 1.6 adet, 100-tane ağırlı̆̆ 38-42 g olarak tespit edilmiştir.

Diyar-95: 1992'de Diyarbakır GAP Uluslararası Tarımsal Araştırma ve Eğitim Merkezi tarafından ıslah edilmiştir. Tane rengi krem, tane tipi koçbaşı ve ortalama verim potansiyeli 150$200 \mathrm{~kg} \mathrm{da}^{-1}$ ' dır. Kışlık ekimde bitki boyu $50-75 \mathrm{~cm}$, bakla sayısı 19-28 adet, çiçeklenme gün sayısı 145-158, olgunlaşma gün sayıs1 182-204, baklada tane sayısı 1.7 adet, 100-tane ağırlığ 40-45 g olarak belirlenmiştir.

ILC-482 (Güney sarısı): 1983'te GAP Uluslararası Tarımsal Araştırma ve Eğitim Merkezi tarafindan ıslah edilmiştir. Tane rengi krem, tane tipi koçbaşı ve ortalama verim potansiyeli $166-200 \mathrm{~kg} \mathrm{da}^{-1}$ ' dır. Kışlık ekimde bitki boyu 40-45 $\mathrm{cm}$, bitkide bakla sayısı 17-27 adet, çiçeklenme gün sayısı 140156 gün, olgunlaşma gün sayısı 170-190 gün, baklada tane sayısı 1-1.5 adet, 100-tane ağırlığı 28-31 g olarak kayıtlara geçmiştir. 


\subsection{Araştırmanın Yapıldığı Yer ve Özellikleri}

Çalışma, Adıyaman il merkezine $5 \mathrm{~km}$ uzaklıkta bulunan İpekli köyü arazileri içindeki, Ali Dağı'nın kuzey yamacına bakan bir çiftçi tarlasında yürütülmüştür.

\subsection{1. İklim Özellikleri}

Nohut bitkisinin yetişme periyodunda 1963-2019 yılları arasındaki uzun yıllar ortalamasına göre Adıyaman iline ait iklim verileri Çizelge 1'de gösterilmiştir (Anonim, 2020). Doğu Anadolu ile Akdeniz Bölgeleri arasında köprü konumunda olan ilin iklimi, bu özelliği dolayısıyla bölgedeki diğer illerden farklidir.

\subsubsection{Toprak Özellikleri}

Vejetasyon periyodu süresince, nohut bitkisine verilecek gübre miktarını belirlemek için, denemenin kurulduğu tarladan toprak örnekleri usulüne uygun olarak alınarak, Adıyaman Firat Toprak Analiz Laboratuarı'nda analiz edilmiştir. Deneme alanındaki toprağın fiziksel ve kimyasal özellikleri Çizelge 2'de verilmiştir.

Çizelge 1. 1963-2019 yılları arasında Adıyaman iline ait iklim verileri (Anonim, 2021)

\begin{tabular}{lcccc}
\hline Aylar & $\begin{array}{c}\text { Ort.Sıcaklık } \\
\left({ }^{\circ} \mathbf{C}\right)\end{array}$ & $\begin{array}{c}\text { Ort.Güneşlenme Süresi } \\
\text { (saat) }\end{array}$ & $\begin{array}{c}\text { Ortalama Yağışlı Gün } \\
\text { Sayısı }\end{array}$ & $\begin{array}{c}\text { Aylık Toplam Yağış Miktarı } \\
\text { Ort.(mm) }\end{array}$ \\
\hline Ocak & 4.4 & 3.7 & 12.5 & 138.7 \\
Şubat & 5.9 & 4.5 & 11.9 & 102.0 \\
Mart & 9.9 & 5.7 & 12.0 & 90.1 \\
Nisan & 15.0 & 7.3 & 11.4 & 66.7 \\
Mayis & 20.4 & 9.3 & 8.5 & 42.6 \\
Haziran & 26.6 & 11.6 & 2.6 & 8.4 \\
Temmuz & 30.9 & 12.1 & 0.6 & 1.7 \\
Ağustos & 30.6 & 11.3 & 0.5 & 1.9 \\
Eylül & 25.8 & 9.7 & 1.4 & 7.6 \\
Ekim & 19.1 & 7.1 & 6.4 & 46.2 \\
Kasım & 11.7 & 5.3 & 8.8 & 75.0 \\
Aralık & 6.5 & 3.7 & 11.9 & 138.9 \\
Y1llık & 17.2 & 91.3 & 88.8 & 719.8 \\
\hline
\end{tabular}

Çizelge 2. Araştırma alanına ait toprak özellikleri

\begin{tabular}{cccccccc}
\hline $\begin{array}{c}\text { Derinlik } \\
(\mathbf{c m})\end{array}$ & $\begin{array}{c}\text { Kum } \\
(\mathbf{\%})\end{array}$ & $\begin{array}{c}\text { Silt } \\
(\mathbf{\%})\end{array}$ & $\begin{array}{c}\text { Kil } \\
(\mathbf{\%})\end{array}$ & $\mathbf{p H}$ & $\begin{array}{c}\text { Tuz } \\
(\boldsymbol{\%})\end{array}$ & $\begin{array}{c}\text { Kireç } \\
(\mathbf{\%})\end{array}$ & $\begin{array}{c}\text { Organik Madde } \\
(\boldsymbol{\%})\end{array}$ \\
\hline $0-30$ & 0.04 & 30.50 & 68.23 & 7.55 & 0.05 & 1.58 & 1.05 \\
$30-60$ & 1.27 & 26.50 & 71.56 & 7.63 & 0.07 & 1.56 & 1.04 \\
$60-90$ & 2.13 & 31.80 & 67.13 & 7.69 & 0.07 & 3.36 & 0.83 \\
\hline
\end{tabular}

\subsection{Metot}

\subsubsection{Tarla Denemesi, Alınan Gözlemler ve Değerlendirmeler}

Ekim; el markörü ile açılan sıralara $30 \mathrm{~cm}$ sıra arası ve $5 \mathrm{~cm}$ sıra üzeri ekim sıklığında, her parselde 4 sıra olacak şekilde yapılmıştır. Bu şekilde 3 tekerrür 27 parselde ekim yapılmıştır. Deneme alanında yabancı ot mücadelesi el ile antraknoz hastalığı ile mücadele ise kimyasal ilaçlama ile yapılmıştır. Tarla denemesi esnasında ve hasat sonrası alınan gözlem ve değerlendirmeler: Bitki çıkış gün sayısı (adet), bitki boyu $(\mathrm{cm})$, bitkide ana dal sayısı (adet), bitkide yan dal sayısı (adet), çiçeklenme gün sayısı, olgunlaşma gün sayısı, bitki başına bakla sayısı (adet), bitki başına bakla ağırlığı $(\mathrm{g})$, dekara tane verimi (kg), 100 tane ağırlığ $(\mathrm{g})$, protein oranı (\%).

\subsubsection{Verilerin Dĕgerlendirilmesi}

Denemede, biri yörede yaygın olarak ekimi yapılan yerel genotip, Diyar-95 ve ILC-482 gibi 3 farklı çeşit ve 3 farklı ekim zamanı (15.01.2017, 25.01.217 ve 04.02.2017) ve 3 tekerrür şeklinde olmak üzere 27 parsel halinde kurulmuştur. Araştırmada elde edilen veriler varyans analizi, MSTAT-C paket programında tekrarlanan tesadüf blokları deneme desenine göre varyans analizine tabi tutulmuş, ortalamalar Duncan testine göre gruplandırılmıştır. Nohut bitkisine ait ilk çıkış görüntüsü, tam çıkış görüntüsü ve gözlem alma aşaması görüntüleri Şekil 1'de, olgunlaşmış bitkiler ve hasat edilmiş tane görüntüleri ise Şekil 2 'de verilmiştir. 

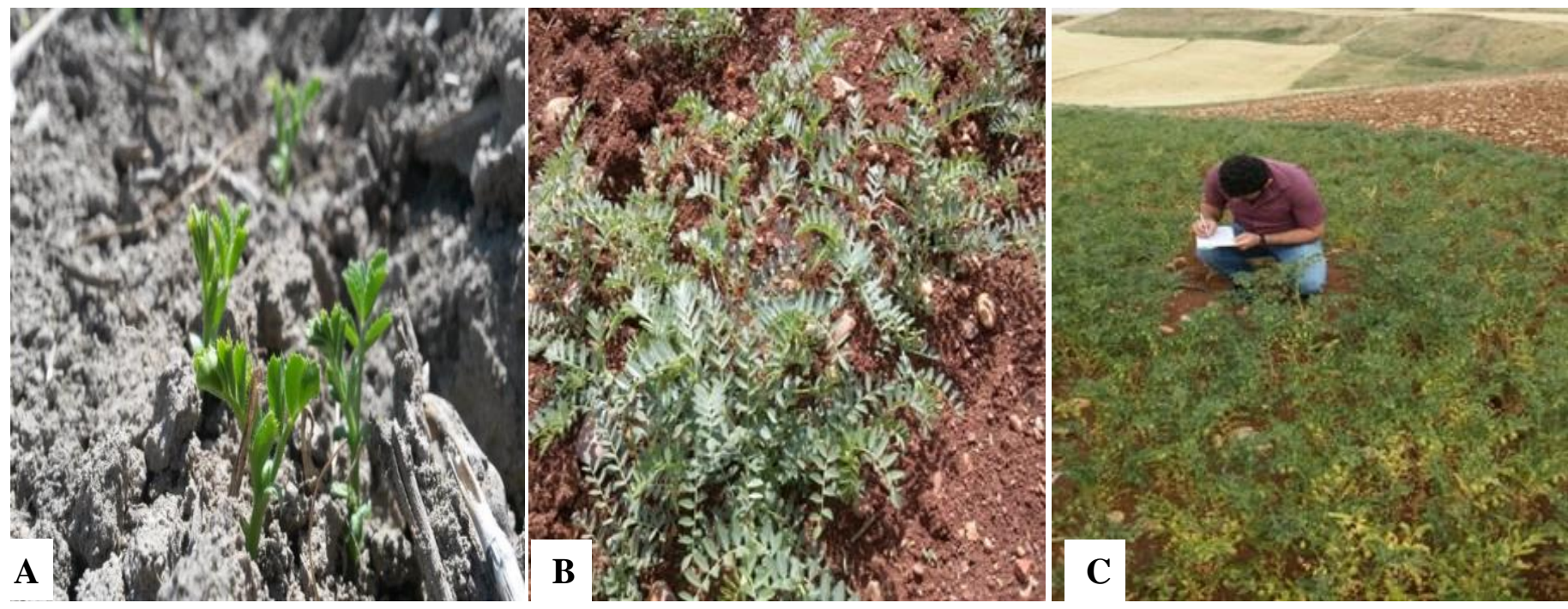

Ssekil 1. Nohut bitkisinin tarla aşamasındaki farklı görüntüleri A) İlk çıkış görüntüsü, B) Tam çıkıs görüntüsü, C) $\quad$ Gözlem alma aşamasi görüntüleri
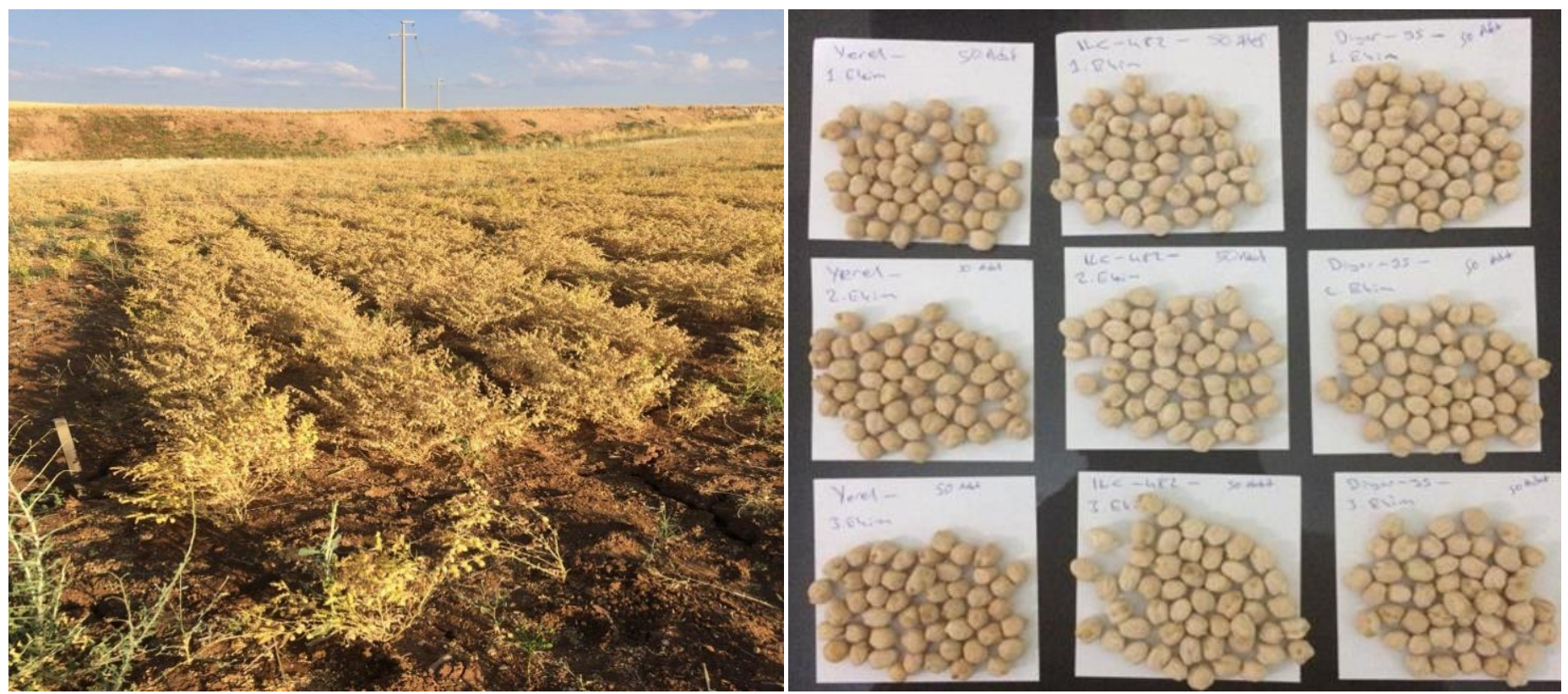

Şekil 2. Olgunlaşmış bitkiler ve hasat edilmiş tane görüntüleri.

\section{Araştırma Sonuçları ve Tartışma}

\subsection{Bitki Çıkış Gün Sayısı}

Ekim zamanlarının bitki çıkış gün sayısı üzerine etkisi önemli $(\mathrm{P}<0.05)$ bulunurken, çeşitler ve ekim zamanı $\times$ çeşit interaksiyonu önemsiz $(\mathrm{P}>0.05)$ olarak belirlenmiştir. En erken çıkış 25 Ocak tarihinde görülmüş (13.55 gün), bunu 4 Şubat (13.66 gün) ve 15 Ocak (15.00 gün) tarihleri takip etmiştir (Çizelge 3).

Elde edilen sonuçlar; Çıtak ve Topak (2016)'ın (15-19.3 gün), Karakan-Kaya (2014)'nın (14.7-19.3 gün) çalışmaları ile benzerlikler, buna karşın Biçer ve Anlarsal (2004)'ın (24.5026.83 gün) araştırmalarından farklılıklar arzetmektedir.

Çizelge 3. Ortalama çıkış gün sayısı değerleri ve varyans analiz tablosu

\begin{tabular}{|c|c|c|c|c|c|c|c|}
\hline \multirow{2}{*}{ Çeşitler } & \multicolumn{3}{|c|}{ Ekim Zamanları } & \multirow{2}{*}{ Çeşit Ort. } & \multirow{2}{*}{$\begin{array}{l}\text { Varyasyon } \\
\text { Kaynakları }\end{array}$} & \multirow{2}{*}{ S.D } & \multirow{2}{*}{$\mathbf{F}$} \\
\hline & 15 Ocak & 25 Ocak & 4 Subat & & & & \\
\hline Diyar-95 & 15.00 & 12.66 & 14.00 & 13.88 & Ekim Zamanı & 2 & $4.00 *$ \\
\hline ILC-482 & 15.00 & 14.00 & 14.00 & 14.33 & Çeşitler & 2 & 0.33 \\
\hline Yerel Genotip & 15.00 & 14.00 & 13.00 & 14.00 & Zaman $\times$ Çeşit & 4 & 0.79 \\
\hline Zaman Ort. & $15.00 \mathrm{~b}$ & $13.55 a$ & $13.66 \mathrm{a}$ & 14.07 & $\begin{array}{ll}* * & : \% 1 \text { seviy } \\
* & : \% 5 \text { seviy }\end{array}$ & $\begin{array}{l}\text { emli } \\
\text { emli }\end{array}$ & \\
\hline
\end{tabular}




\subsection{Bitki Boyu (cm)}

Ekim zamanlarının ve çeşitlerin bitki boyu üzerine etkisi çok önemli $(\mathrm{P}<0.01)$, buna karşın ekim zamanı $\times$ çeşit interaksiyonunun önemsiz ( $\mathrm{P}>0.05)$ olduğu görülmüştür. Farklı ekim zamanlarında; en uzun bitkiler 15 Ocak'ta elde edilmiş $(34.80 \mathrm{~cm})$, bunu 25 Ocak $(32.06 \mathrm{~cm})$ ve 4 Şubat ekimleri $(24.56$ cm) takip etmiştir. Çeşitlerden en uzun bitkiler ILC-482 çeşidinden elde edilmiş $(33.40 \mathrm{~cm})$, bunu Diyar-95 $(29.66 \mathrm{~cm})$ ve yerel genotip $(28.36 \mathrm{~cm})$ takip etmiştir (Çizelge 4$).$
Sonuçlar, Bakoğlu ve Ayçiçek (2005)'in (32.8 cm), Düzdemir ve ark. (2007)'nın (28.1-48.4 cm) ve Uzun ve ark. (2012)'nın (34.2-40.2 cm) çalışmalarıyla benzerlikler göstermekte, buna karşın Babagil (2011)'in (42.6-49.7 cm), Karakan Kaya (2014)'nın (41.2-56.9 cm), Bayrak ve ark. (2015)'nın (43.2 cm), Yalçın ve ark. (2018)'nın (38.2-41.9 cm), Ercan ve ark. (2019)'nın (30.5-47.4 cm)'nın, Demirci ve Bildirici (2020)'nin (39-48 cm) ve Uçar ve ark. (2020)'nin $(51.0-57.5 \mathrm{~cm})$ sonuçlarıyla farklılıklar arzetmektedir.

Çizelge 4. Bitki boyu (cm) değerleri ve varyans analiz tablosu

\begin{tabular}{|c|c|c|c|c|c|c|c|}
\hline \multirow{2}{*}{ Çeşitler } & \multicolumn{3}{|c|}{ Ekim Zamanları } & \multirow{2}{*}{ Çeşit Ort. } & \multirow{2}{*}{$\begin{array}{l}\text { Varyasyon } \\
\text { Kaynakları }\end{array}$} & \multirow{2}{*}{ S.D } & \multirow{2}{*}{$\mathbf{F}$} \\
\hline & 15 Ocak & 25 Ocak & 4 Şubat & & & & \\
\hline Diyar-95 & 35.80 & 33.30 & 19.90 & $29.66 b$ & Ekim Zamanı & 2 & $112 * *$ \\
\hline ILC-482 & 36.10 & 34.60 & 33.40 & 33.40a & Çeşitler & 2 & $62.1 * *$ \\
\hline Yerel Genotip & 32.50 & 28.30 & 28.36 & $28.36 b$ & Zaman $\times$ Çeşit & 4 & 1.35 \\
\hline Zaman Ort. & 34.80a & 32.06a & $24.56 b$ & & $\begin{array}{l}* * \quad: \% 1 \text { seviy } \\
* \quad: \% 5 \text { seviye }\end{array}$ & nemli & \\
\hline
\end{tabular}

\subsection{Bitki Başına Ana Dal Sayısı (adet/bitki)}

Ekim zamanlarının bitkide ana dal sayısı üzerine etkisi çok önemli $(\mathrm{P}<0.01)$ olarak belirlenmiş, buna karşın çeşit ve ekim zamanı $\times$ çeşit interaksiyonunun önemsiz $(\mathrm{P}>0.05)$ olduğu görülmüştür. Farklı ekim zamanlarında en fazla ana dal sayısının 25 Ocak ekiminden elde edildiği (2.76 adet), bunu 15 Ocak ekiminin takip ettiği (2.63 adet) ve 4 Şubat ekiminin en az dal sayısı verdiği (2.56 adet) görülmektedir (Çizelge 5).
Nohut bitkisinde ekim zamanının ana dal sayısını etkilediği (Üstün ve Gülümser, 2003; Yiğitoğlu ve Anlarsal, 2012), elde edilen sonuçların Ercan ve ark. (2019)'nın (1.71-2.73) belirlediği ana dal sayılarıyla benzerlikler gösterdiği, buna karşın (Doğan (2014)'nın (3.1-4.1 adet), Karakan Kaya (2014)'nın (3.0-4.4 adet), Rezaei (2012)'nin (3.00-3.90 adet) verilerinden farklılıklar gösterdiği görülmektedir.

Çizelge 5. Bitki başına ana dal sayısı (adet) değerleri ve varyans analiz tablosu

\begin{tabular}{|c|c|c|c|c|c|c|c|}
\hline \multirow{2}{*}{ Çeşitler } & \multicolumn{3}{|c|}{ Ekim Zamanları } & \multirow{2}{*}{ Çeşit Ort. } & \multirow{2}{*}{$\begin{array}{l}\text { Varyasyon } \\
\text { Kaynakları }\end{array}$} & \multirow{2}{*}{ S.D } & \multirow{2}{*}{$\mathbf{F}$} \\
\hline & 15 Ocak & 25 Ocak & 4 Şubat & & & & \\
\hline Diyar-95 & 2.70 & 2.80 & 2.50 & 2.66 & Ekim Zamanı & 2 & $13.2 * *$ \\
\hline ILC-482 & 2.60 & 2.90 & 2.30 & 2.60 & Çeşitler & 2 & 3.29 \\
\hline Yerel Genotip & 2.60 & 2.60 & 2.60 & 2.60 & Zaman $\times$ Çeşit & 4 & 4.71 \\
\hline Zaman Ort. & $2.63 b$ & $2.76 a$ & $2.56 \mathrm{~b}$ & 2.65 & $\begin{array}{ll}* * & : \% 1 \text { seviy } \\
* & : \% 5 \text { seviy }\end{array}$ & $\begin{array}{l}\text { nemli } \\
\text { nemli }\end{array}$ & \\
\hline
\end{tabular}

\subsection{Bitki Başına Yan Dal Sayısı (adet)}

Nohut çeşitleri, ekim zamanları ve ekim zamanı $\times$ çeşit interaksiyonlarının bitkide yan dal sayısı üzerine etkisi çok önemli $(\mathrm{P}<0.01)$ bulunmuştur. Farklı ekim zamanlarında en fazla yan dal sayısının 4 Şubat ekiminden (8.74 adet), çeşitlerden ise ILC-482 çeşidinden ( 8.82 adet) elde edildiği belirlenmiştir.
İnteraksiyonlarda; en fazla yan dal sayısı 4 Şubat'ta ekilen ILC-482 çeşidinden elde edilmiş (8.92 adet), bunu 15 Ocak'ta ekilen ILC-482 çeşidi (8.81 adet) ve 25 Ocak'ta ekilen yerel genotipten (8.56 adet) elde edildiği ortaya konulmuştur (Çizelge 6). Sonuçlar; Topalak ve Ceyhan (2015)'ın (7.45-7.96 adet) sonuçlarıyla benzerlikler, buna karşın Rezaei (2012)'nin çalışmasından (5.12-6.25 adet) farklılıklar arzetmektedir.

Çizelge 6. Bitki başına yan dal sayısı (adet) ve varyans analiz tablosu

\begin{tabular}{|c|c|c|c|c|c|c|c|}
\hline \multirow{2}{*}{ Çeşitler } & \multicolumn{3}{|c|}{ Ekim Zamanları } & \multirow{2}{*}{ Çeşit Ort. } & \multirow{2}{*}{$\begin{array}{l}\text { Varyasyon } \\
\text { Kaynakları }\end{array}$} & \multirow{2}{*}{ S.D } & \multirow{2}{*}{$\mathbf{F}$} \\
\hline & 15 Ocak & 25 Ocak & 4 Şubat & & & & \\
\hline Diyar-95 & $8.72 \mathrm{~d}$ & $8.63 \mathrm{~g}$ & $8.70 \mathrm{e}$ & $8.68 \mathrm{~b}$ & Ekim Zamanı & 2 & $148 * *$ \\
\hline ILC-482 & $8.81 \mathrm{~b}$ & $8.74 \mathrm{c}$ & $8.92 a$ & 8.82a & Çeşitler & 2 & $561 * *$ \\
\hline Yerel Genotip & $8.68 \mathrm{f}$ & $8.56 \mathrm{i}$ & $8.60 \mathrm{~h}$ & $8.61 \mathrm{~b}$ & Zaman $\times$ Çeşit & 4 & $42.3^{* *}$ \\
\hline Zaman Ort. & $8.73 a$ & $8.64 \mathrm{~b}$ & $8.74 a$ & 8.70 & $\begin{array}{l}* * \quad: \% 1 \text { seviy } \\
* \quad: \% 5 \text { seviy }\end{array}$ & nemli & \\
\hline
\end{tabular}




\section{5.Çiçeklenme Gün Sayısı}

Ekim zamanlarının çiçeklenme gün sayısına etkisi çok önemli $(\mathrm{P}<0.01)$, çeşit ve ekim zamanı $\times$ çeşit interaksiyonunun önemsiz $(\mathrm{P}>0.05)$ olduğu tespit edilmiştir. Ekim zamanları arasında çiçeklenme gün sayılarının 75-79 gün arasında değiştiği, en erken çiçeklenme gün sayısının, 15 Ocak ekiminden, elde edildiği ( 75 gün), bunu 25 Ocak ekiminin takip ettiği (77 gün) ve 4 Şubat ekiminde en geç çiçeklenmenin görüldüğü (79 gün) ortaya çıkmıştır (Çizelge 7).
Elde edilen sonuçların, Biçer ve Anlarsal (2004)'ın (76.284.6 gün) ve Uzun ve ark. (2012)'nın (60.14-62.86 gün) bulgularıyla benzerlikler, buna karşın Rezaei (2012)'nin (31.5035.75 gün), Karakan Kaya (2014)'nın (57-62.3 gün), Bayrak ve ark. (2015)'nın (56.5 gün) ve Demirci ve Bildirici (2020)'nin (47.3-53.6 gün) sonuçlarıyla farklılıklar arzetmektedir. Çalışmada kullanılan çeşitlerin ve araştırmanın yapıldığ lokasyonun bu farklılıklara neden olabileceği düşünülmektedir.

Çizelge 7. Çiçeklenme gün saylsı değerleri ve varyans analiz tablosu

\begin{tabular}{|c|c|c|c|c|c|c|c|}
\hline \multirow{2}{*}{ Çeşitler } & \multicolumn{3}{|c|}{ Ekim Zamanları } & \multirow{2}{*}{ Çeşit Ort. } & \multirow{2}{*}{$\begin{array}{l}\text { Varyasyon } \\
\text { Kaynakları }\end{array}$} & \multirow{2}{*}{ S.D } & \multirow{2}{*}{$\mathbf{F}$} \\
\hline & 15 Ocak & 25 Ocak & 4 Şubat & & & & \\
\hline Diyar-95 & 75 & 77 & 79 & 77 & Ekim Zamanı & 2 & $13.8 * *$ \\
\hline ILC-482 & 75 & 77 & 79 & 77 & Çeşitler & 2 & 1.00 \\
\hline Yerel Genotip & 75 & 77 & 79 & 77 & Zaman $\times$ Çeşit & 4 & 1.00 \\
\hline Zaman Ort. & $75 \mathbf{a}$ & $77 b$ & $79 c$ & 77 & $\begin{array}{ll}* * & : \% 1 \text { seviy } \\
* & : \% 5 \text { seviy }\end{array}$ & $\begin{array}{l}\text { eemli } \\
\text { eemli }\end{array}$ & \\
\hline
\end{tabular}

\subsection{Olgunlaşma Gün Sayısı}

Çeşitlerin ve ekim zamanlarının olgunlaşma gün sayısına etkisi çok önemli $(\mathrm{P}<0.01)$ olarak belirlenmiştir. En erken olgunlaşma 15 Ocak ekiminde görülmüş (118 gün), bunu 25 Ocak (121.33 gün) ve 4 Şubat (124 gün) ekim zamanları takip etmiştir. Çeşitler arasında, en erken olgunlaşma ILC-482 çeşidinde görülmüş (113.33 gün), bunu yerel genotip (123 gün) ve Diyar-95 çeşidi (127 gün) takip etmiştir (Çizelge 8).
Elde edilen bulguların, Uzun ve ark. (2012)'nın (118.50123.16 gün) sonuçlarıyla benzerlikler gösterdiği, buna karşın Karakan Kaya (2014)'nın, (70.30-72.30 gün), Güngör ve Dumlupınar (2018)'nın (78.5-89 gün), Ercan ve ark. (2019)'nın (71.75-84.75 gün)'nın ve Demirci ve Bildirici (2020)'nin (69.379.3) sonuçlarıyla farklılıklar arzetmektedir.

Çizelge 8. Olgunlaşma gün sayısı değerleri ve varyans analiz tablosu

\begin{tabular}{|c|c|c|c|c|c|c|c|}
\hline \multirow{2}{*}{ Çeşitler } & \multicolumn{3}{|c|}{ Ekim Zamanları } & \multirow{2}{*}{ Çeşit Ort. } & \multirow{2}{*}{$\begin{array}{l}\text { Varyasyon } \\
\text { Kaynakları }\end{array}$} & \multirow{2}{*}{ S.D } & \multirow{2}{*}{$\mathbf{F}$} \\
\hline & 15 Ocak & 25 Ocak & 4 Şubat & & & & \\
\hline Diyar-95 & 123 & 128 & 130 & $127.00 \mathrm{c}$ & Ekim Zamanı & 2 & $59.8 * *$ \\
\hline ILC-482 & 110 & 113 & 117 & 113.33a & Çeşitler & 2 & $326 * *$ \\
\hline Yerel Genotip & 121 & 123 & 125 & 123.00b & Zaman $\times$ Çeşit & 4 & 2.45 \\
\hline Zaman Ort. & 118.00a & $121.33 b$ & $124.00 \mathrm{c}$ & 121.11 & $\begin{array}{ll}* * & : \% 1 \text { seviy } \\
* & : \% 5 \text { seviy }\end{array}$ & $\begin{array}{l}\text { nemli } \\
\text { nemli }\end{array}$ & \\
\hline
\end{tabular}

\subsection{Bitkide Bakla Sayısı (adet)}

Çeşitler ve ekim zamanı $\times$ çeşit interaksiyonu önemli bulunmuş $(\mathrm{P}<0.05)$, buna karşın ekim zamanının etkisinin önemsiz olduğu $(\mathrm{P}>0.05)$ görülmüştür. Çeşitlerden; en yüksek bakla sayısı ILC-482 çeşidinden elde edilmiş (43.78 adet), bunu yerel genotip (43.63 adet) ve Diyar-95 çeşidi (41.93 adet) takip etmiştir (Çizelge 9).
Elde edilen sonuçlar, Yolcu (2008)'nun (36.8-69.9 adet) çalışmasıyla benzerlikler göstermekte, ancak Doğan (2014)'nın (21.7-34.5 adet), Kaya ve ark. (2008)'nın (11.7-17.1 adet), Ercan ve ark. (2019)'nın (13.38-18.04 adet), Demirci ve Bildirici (2020)'nin (6.9-13.0 adet) ve Uçar ve ark. (2020)'nın (30.2-34.2) belirlediği bakla sayılarından daha yüksek değerler verdiği görülmüştür.

Çizelge 9. Bitkide bakla sayısı (adet) değerleri ve varyans analiz tablosu

\begin{tabular}{|c|c|c|c|c|c|c|c|}
\hline \multirow{2}{*}{ Çeşitler } & \multicolumn{3}{|c|}{ Ekim Zamanları } & \multirow{2}{*}{ Çeşit Ort. } & \multirow{2}{*}{$\begin{array}{l}\text { Varyasyon } \\
\text { Kaynakları }\end{array}$} & \multirow{2}{*}{ S.D } & \multirow{2}{*}{$\mathbf{F}$} \\
\hline & 15 Ocak & 25 Ocak & 4 Şubat & & & & \\
\hline Diyar-95 & $38.71 \mathrm{~b}$ & $44.15 \mathrm{a}$ & $42.93 \mathrm{ab}$ & 41.91b & Ekim Zamanı & 2 & 2.71 \\
\hline ILC-482 & $44.03 \mathrm{a}$ & $43.78 \mathrm{a}$ & $43.53 \mathrm{a}$ & 43.78a & Çeşitler & 2 & $3.98 *$ \\
\hline Yerel Genotip & $43.78 \mathrm{a}$ & $43.56 \mathrm{a}$ & $43.56 \mathrm{a}$ & 43.63a & Zaman $\times$ Çeşit & 4 & $3.79 *$ \\
\hline Zaman Ort. & 42.17 & 43.83 & 43.34 & 43.11 & $\begin{array}{l}* * \quad: \% 1 \text { seviye } \\
* \quad: \% 5 \text { seviye }\end{array}$ & nemli & \\
\hline
\end{tabular}




\subsection{Bitkide Bakla Ağırlığı (g)}

Nohut çeşitlerinin, ekim zamanının ve ekim zamanı×çeşit interaksiyonunun önemsiz olduğu $(\mathrm{P}>0.05)$ görülmüştür. Bütün uygulamalar ve interaksiyon önemsiz olarak belirlendiğinden ve bitki başına bakla ağırlığı ile ilgili karşılaştırmalı literatür bulunamadığından değerlendirme yapılamamıştır (Çizelge 10).

Çizelge 10. Bakla ăğrlı̆̆ (g) değerleri ve varyans analiz tablosu

\begin{tabular}{|c|c|c|c|c|c|c|c|}
\hline \multirow{2}{*}{ Çeşitler } & \multicolumn{3}{|c|}{ Ekim Zamanları } & \multirow{2}{*}{ Çeşit Ort. } & \multirow{2}{*}{$\begin{array}{l}\text { Varyasyon } \\
\text { Kaynakları }\end{array}$} & \multirow[b]{2}{*}{ S.D } & \multirow[b]{2}{*}{ F } \\
\hline & 15 Ocak & 25 Ocak & 4 Şubat & & & & \\
\hline Diyar-95 & 23.51 & 24.88 & 23.87 & 24.08 & Ekim Zamanı & 2 & 1.05 \\
\hline ILC-482 & 22.92 & 23.52 & 24.63 & 23.69 & Çeşitler & 2 & 2.02 \\
\hline Yerel Genotip & 22.13 & 23.24 & 22.52 & 22.63 & Zaman $\times$ Çeşit & 4 & 0.41 \\
\hline Zaman Ort. & 22.85 & 23.88 & 23.67 & 23.46 & $\begin{array}{ll}* * \% 1 \text { seviye } \\
* \quad: \% 5 \text { seviye }\end{array}$ & emli & \\
\hline
\end{tabular}

\subsection{Dekara Tane Verimi $(\mathrm{kg})$}

Nohut çeşitleri ile ekim zamanı $\times$ çeşit interaksiyonunun tane verimi üzerine etkisinin önemli olduğu $(\mathrm{P}<0.01)$, buna karşın ekim zamanlarının önemsiz $(\mathrm{P}>0.05)$ bulunduğu görülmektedir. Dekara en yüksek verim yerel genotipten elde edilmiş (180.64 kg), bunu ILC-482 (173.03 kg) ve Diyar-95 $(162.40 \mathrm{~kg})$ çeşitleri takip etmiştir. İnteraksiyonlar incelendiğinde; en yüksek verim yerel genotipten 25 Ocak'taki ekimden alınmış, (182.60 kg), bunu aynı çeşidin 4 Şubat (180.8 $\mathrm{kg})$ ve 15 Ocak $(178.5 \mathrm{~kg})$ tarihlerinin takip ettiği, en düşük verimin ise 25 Ocakta ekimi yapılan Diyar-95 çeşidinden $(155.40 \mathrm{~kg}$ ) elde edildiği ortaya konulmuştur (Çizelge 11).
Elde edilen sonuçlar, Kaya ve ark. (2008)'nın (89.1-175.6 $\mathrm{kg} \mathrm{da}{ }^{-1}$ ), Yolcu (2008)'nun (127.51-192.02 kg da-1), KarakanKaya (2014)'nın (123.1-214.9 kg da $\left.{ }^{-1}\right)$, Topalak ve Ceyhan (2015)'ın (110.7-217.1 kg da ${ }^{-1}$ ) ve Uçar ve ark. (2020)'nın (169.7-208.2 $\mathrm{kg} \mathrm{da}^{-1}$ ) bulguları ile benzerlik göstermektedir. Buna karşın, Düzdemir ve ark. (2007)'nın (94.90-153.1 kg da-1) ve Rezaei (2012)'nin (91.40-164.60 kg da-1) değerlerinden daha yüksek, 141.7-277.4 kg da-1 Doğan (2014)'ın (141.7-277.4 kg $\mathrm{da}^{-1}$ ), Ercan ve ark. (2019)'nın (168.5-302.2 $\left.\mathrm{kg} \mathrm{da}^{-1}\right)$ ve Demirci ve Bildirici (2020)'nin (140.6-398.7 $\mathrm{kg} \mathrm{da}^{-1}$ ) bulgularından ise daha düşük değerler elde edildiği görülmektedir.

Çizelge 11. Dekara tane verimi (kg) değerleri ve varyans analiz tablosu

\begin{tabular}{|c|c|c|c|c|c|c|c|}
\hline \multirow{2}{*}{ Çeşitler } & \multicolumn{3}{|c|}{ Ekim Zamanları } & \multirow{2}{*}{ Çeşit Ort. } & \multirow{2}{*}{$\begin{array}{l}\text { Varyasyon } \\
\text { Kaynakları }\end{array}$} & \multirow{2}{*}{ S.D } & \multirow{2}{*}{$\mathbf{F}$} \\
\hline & 15 Ocak & 25 Ocak & 4 Şubat & & & & \\
\hline Diyar-95 & $164.70 \mathrm{e}$ & $155.40 \mathrm{f}$ & $167.10 \mathrm{e}$ & $162.40 \mathrm{c}$ & Ekim Zamanı & 2 & 3.25 \\
\hline ILC-482 & $169.20 \mathrm{de}$ & $175.6 b c$ & $174.3 \mathrm{~cd}$ & 173.03b & Çeşitler & 2 & $85.3^{* *}$ \\
\hline Yerel Genotip & $178.5 \mathrm{abc}$ & $182.60 \mathrm{a}$ & $180.8 \mathrm{ab}$ & $180.64 a$ & Zaman $\times$ Çeşit & 4 & $7.5 * *$ \\
\hline Zaman Ort. & 170.80b & 171.20ab & $174.07 a$ & 172.02 & $\begin{array}{ll}* * & : \% 1 \text { seviy } \\
* & : \% 5 \text { seviy }\end{array}$ & emli & \\
\hline
\end{tabular}

\subsection{0-tane A ğırlığı (g)}

Çeşitlerin 100 tane ağırlığı üzerine etkisi çok önemli $(\mathrm{P}<0,01)$ bulunmuş, buna karşın ekim zamanlarının ve ekim zamanı $\times$ çeşit interaksiyonunun 100 tane ağırlığ 1 üzerine etkisinin önemsiz $(\mathrm{P}>0.05)$ olduğu görülmektedir. Çeşitler değerlendirildiğinde; en fazla 100-tane ağırlığı Diyar-95'ten elde edilmiş (39.74 g), bunu ILC-482 (37.70 g) ve yerel $(36.37 \mathrm{~g})$ genotiplerinin takip ettiği görülmektedir (Çizelge 12).
Elde edilen sonuçlar; Doğan (2014)'nın (31.3-43.6 g), Karakan-Kaya (2014)'nın (25.6-38.5 g), Yolcu (2008)'nun (34,2-36,4 g), Ercan ve ark. (2019)'nın (29.74-38.72 g), Demirci ve Bildirici (2020)'nin (29.5-39.8 g) ve Uçar ve ark. (2020)'nın (31.2-35.4 g) elde ettikleri bulgular ile ile benzerlikler göstermektedir.

Çizelge 12. Yüz tane ă̆ırlı̆̆ (g) değerleri ve varyans analiz tablosu

\begin{tabular}{|c|c|c|c|c|c|c|c|}
\hline \multirow{2}{*}{ Çeşitler } & \multicolumn{3}{|c|}{ Ekim Zamanları } & \multirow{2}{*}{ Çeşit Ort. } & \multirow{2}{*}{$\begin{array}{l}\text { Varyasyon } \\
\text { Kaynakları }\end{array}$} & \multirow{2}{*}{ S.D } & \multirow{2}{*}{$\mathbf{F}$} \\
\hline & 15 Ocak & 25 Ocak & 4 Şubat & & & & \\
\hline Diyar-95 & 39.55 & 38.42 & 41.25 & 39.74a & Ekim Zamanı & 2 & 2.23 \\
\hline ILC-482 & 37.15 & 38.68 & 37.27 & 37.70b & Çeşitler & 2 & $14.4 * *$ \\
\hline Yerel Genotip & 36.25 & 35.28 & 37.58 & $36.37 b$ & Zaman $\times$ Çeşit & 4 & 2.29 \\
\hline Zaman Ort. & 37.65 & 37.46 & 38.70 & 37.93 & $\begin{array}{ll}* * & : \% 1 \text { seviye } \\
* & : \% 5 \text { seviye }\end{array}$ & $\begin{array}{l}\text { nemli } \\
\text { nemli }\end{array}$ & \\
\hline
\end{tabular}




\subsection{Protein Oranı (\%)}

İncelenen bütün karakterlerin ve interaksiyonun nohut tanesindeki protein oranı üzerine etkisinin önemsiz $(\mathrm{P}>0.05)$ bulunduğu görülmektedir (Çizelge 13).
Elde edilen bulgular Yalçın ve ark. (2018)'nın (\%21.6624.91) çalışmasıyla benzerlik, Ercan ve ark. (2019)'nın (22.80) araştırmasıyla ise farklılık göstermektedir.

Çizelge 13. Protein oranı (\%) değerleri ve varyans analiz tablosu

\begin{tabular}{|c|c|c|c|c|c|c|c|}
\hline \multirow{2}{*}{ Çeşitler } & \multicolumn{3}{|c|}{ Ekim Zamanları } & \multirow{2}{*}{ Çeşit Ort. } & \multirow{2}{*}{$\begin{array}{l}\text { Varyasyon } \\
\text { Kaynakları }\end{array}$} & \multirow{2}{*}{ S.D } & \multirow{2}{*}{$\mathbf{F}$} \\
\hline & 15 Ocak & 25 Ocak & 4 Şubat & & & & \\
\hline Diyar-95 & 26.50 & 27.80 & 26.70 & 27.00 & Ekim Zamanı & 2 & 0.84 \\
\hline ILC-482 & 27.20 & 27.80 & 26.40 & 27.13 & Çeşitler & 2 & 2.8 \\
\hline Yerel Genotip & 25.60 & 25.70 & 25.60 & 25.63 & Zaman $\times$ Çeşit & 4 & 0.25 \\
\hline Zaman Ort. & 26.43 & 27.10 & 26.23 & 26.58 & $\begin{array}{ll}* * & : \% 1 \text { seviy } \\
* & : \% 5 \text { seviy }\end{array}$ & nemli & \\
\hline
\end{tabular}

\section{Sonuç ve Öneriler}

Çeşitler incelendiğinde; ILC-482 çeşidinin, bitki boyu, yan dal sayısı, olgunlaşma gün sayısı bitkide bakla sayısı ve protein oranı yönünden ön planda olduğu, Diyar-95 çeşidinin çıkış gün sayısı ana dal sayısı, bitkide bakla ağırlığı ve 100-tane ağırlığ1 bakımından dikkat çektiği, yerel genotipin ise incelenen diğer parametreler yönünden avantajlı durumda olduğu belirlenmiştir.

Ekim zamanlarına bakıldığında; 25 Ocak tarihinin çıkış gün sayısı, ana dal sayısı, bitkide bakla sayısı, bitkide bakla ağırlığ ve protein oranı yönünden ön planda olduğu, 4 Şubat ekiminin yan dal sayısı, 100-tane ağırlığ 1 ve dekara tane verimi yönünden dikkat çektiği, 15 Ocak tarihinin ise diğer bazı karakterler yönünden olumlu özellikler gösterdiği görülmektedir.

Çeşitler $\times$ ekim zamanları interaksiyonları incelendiğinde; çıkış sürelerinin 12.66-15.00 gün, bitki boylarının 19.90-36.10 $\mathrm{cm}$, ana dal sayılarının 2.30-2.90 adet, yan dal sayılarının 8.568.92 adet, çiçeklenme gün sürelerinin 75-79 gün, olgunlaşma gün sürelerinin 110-130 gün, bitkide bakla sayılarının 38.7144.15 adet, bitkide bakla ağırlığının 22.13-24.88 g, dekara tane veriminin $155.40-182.60 \mathrm{~kg} \mathrm{da}{ }^{-1}$, 100-tane ağırlığının 35.28 $41.25 \mathrm{~g}$, danede protein oranının \%25.60-27.80 arasında değiştiği ortaya konulmuştur. Sonuç olarak; 25 Ocak tarihindeki ekim zamanının ve çalışmada kullanılan çeşitlerin, nohutun verim ve verim bileşenleri üzerine katkısının önemli olduğu, bu nedenle Adıyaman ve çevresi için bu çeşitlerin ve ekim zamanının tavsiye edilebileceği sonucuna varılmıştır.

Bütün bu değerlendirmelere bakıldığında yerel genotipten elde edilen verim ve verim bileşenlerinin, 1slah edilmiş diğer ticari çeşitlerden istatistiki anlamda çok önemli farklılıklar göstermediği ve bu nedenle Adıyaman ve çevresi için yerel genotipin de diğer kültür çeşitleri ile birlikte tavsiye edilebileceği, yerel genotipin bazı özelliklerini geliştirmek için ıslah programlarına alınmasının ve çiftçilerin hizmetine sunulmasının doğru olacağı sonucuna varılmıştır. Ekim zamanlarından 25 Ocak ve sonraki tarihlerde yapılan ekimlerin tane verimi değerleri yönünden daha üstün özellikler göstermesinden dolayı, ekstrem iklim verileri de dikkate alınmak suretiyle, Adiyaman ve çevresi çiftçileri için 25 Ocaktan başlayarak Şubat ayının ilk haftasına kadar nohut ekimlerinin yapılabileceği tavsiye edilmiştir.

\section{Teşekkür}

Bu makale Iğdır Üniversitesi Fen Bilimleri Enstitüsü’nde Yüksek Lisans Öğrencisi Veli Sönmez tarafindan tamamlanan "Adıyaman Ekolojik Koşullarında Farklı Ekim Zamanlarında Bazı Nohut (Cicer arietinum L.) Çeşitlerinin Verim ve Kalite Özelliklerinin Belirlenmesi” başlıklı yüksek lisans tezinden uyarlanarak hazırlanmıştır.

\section{Araştırmacıların Makaleye Katkı Oranı ve Çıkar Çatışması Beyanı}

Yazarlar makaleye eşit oranda katkı sağlamış olduklarını ve makalelerinde sonuçları veya yorumları etkileyebilecek herhangi bir maddi veya diğer çıkar çatışması olmadığını beyan ederler.

\section{Kaynakça}

Akdağ, C., Ütebay, H., Düzdemir, O. (1995). Ekim Zamanı, Azot ve Fosfor Dozlarının Nohutta Verim ve Diğer Bazı Özelliklere Etkileri Üzerine Bir Araştırma. Gaziosmanpaşa Üniversitesi Ziraat Fakültesi Dergisi, 12, 110-121.

Ali, Y., Biswas, P. K., Shahriar, S. A., Nasif, S. O., Raihan, R. R. (2018). Yield and QualityResponse of Chickpe at DifferentSowingDates. AsianJournal of Research in CropScience, 1 (4), 1-8.

Anlarsal, A., Yücel, C., Özveren, D. (1999). Çukurova Koşullarında Bazı Nohut (Cice rarietinumL.) Hatlarının Verim ve Verimle İlgili Özelliklerinin Saptanması Üzerine Bir Araştırma. Türkiye 3. Tarla Bitkileri Kongresi. Cilt III, Adana, p: 342-347.

Anonim. (2021). Meteoroloji Genel Müdürlüğü, Adryaman İklim Verileri.

https://www.mgm.gov.tr/veridegerlendirme/il-ve-ilceleristatistik.aspx?m=ADIYAMAN

Avelar, R. I. S., da Costa, C. A., da SilvaBrandãoJúnior, D., Paraíso, H. A., Nascimento, W. M., (2018). Production and Quality of ChickpeaSeeds in DifferentSowing and Harvest Periods. Journal of Seed Science, 40 (2), 146-155.

Aydemir, L. Y. ve Yemenicioĝlu, A. (2013). Potential of Turkish Kabuli type chickpea and green and red lentil cultivars as source of soy and animal origin functional protein alternatives. LWT - Food Science and Technology, 50 (2), 686-694. 
Babagil, G.E. (2011). Erzurum Ekolojik Koşullarında Bazı Nohut (Cicer arietinum L.) Çeşitlerinin Verim ve Verim Özelliklerinin İncelenmesi. Anadolu Tarım Bilimleri Dergisi, 26 (2), 122-127.

Bakoğlu, A., Ayçiçek, M. (2005). Bingöl Ekolojik Koşullarında Bazı Nohut (Cicer arietinum L.) Çeşitlerinin Verim ve Verim Öğeleri Üzerine Bir Araştırma. Firat Üniversitesi Fen ve Mühendislik Bilimleri Dergisi, 17 (1), 107-113.

Bayrak, H., Keleş, R., İmriz, G. (2015). İleri Kademe Nohut Hatlarının ve Çeşitlerin Konya Ekolojisindeki Bazı Verim Karakterlerinin Belirlenmesi. Bahri Dă̆daş Bitkisel Araştırma Dergisi, 4 (2), 32-37.

Biçer, B. T., Anlarsal A. E. (2004). Bazı Nohut (Cicer arietinum L.) Köy Çeşitlerinde Bitkisel ve Tarımsal Özelliklerin Belirlenmesi. Dicle Üniversitesi Tartm Bilimleri Dergisi, 10 (4), 389-396.

Çıtak, G., Topak, R. (2016). Farklı Sulama Programları Uygulamasının Nohutta Verim ve Kaliteye Etkisi. Selçuk Tarım Bilimleri Dergisi, 3 (6), 45-56.

Demirci, Ö. \& Bildirici, N. (2020). Şanlıurfa Ekolojik Koşullarında Yetiştirilen Bazı Nohut (Cicer arietinum L.) Çeşitlerinin Verim ve Verim Unsurlarının Belirlenmesi. Avrupa Bilim ve Teknoloji Dergisi, (20), 656-662.

Doğan, Y. (2014). Mardin Kızıltepe Ekolojik Koşullarında Kışlık Olarak Yetiştirilebilecek Nohut Çeşitlerinin Belirlenmesi. Gaziosmanpaşa Üniversitesi Ziraat Fakültesi Dergisi, 31 (1), 37-46.

Düzdemir, O., Akdağ, C., Yanar. Y. (2007). Bazı Nohut (Cicer arietinum L.) Çeşitlerinin Farklı İklim Koşullarında Antraknoz Dayanımları ve Tane Verimleri Üzerine Araştırma. Gaziosmanpaşa Üniversitesi Ziraat Fakültesi Dergisi, 24 (2), 87-97.

Elis, S., Ipekesen, S., Basdemir, F., Tunc, M., Bicer, B.T. (2020). Effect of DifferentFertilizer Forms on Yield and Yield Components of ChickpeaVarieties. International Journal of Agriculture, Environment, Food Science, 4 (2), 209-215.

Ercan, M. Y. İ., Uzun, S., Özaktan, H. (2019). Kayseri Ekolojik Koşullarında Farklı Ekim Zamanlarının Nohut (Cicer arietinum L.) Bitkisinde Verim, Verim Unsurları ve Kalite Üzerine Etkileri. Avrupa Bilim ve Teknoloji Dergisi, (16), 434-440.

Erman, M., Tüfenkçi, Ş. (2004). Farklı Ekim Zamanlarının Nohutta (Cicer arietinum L.) Verim ve Verimle İlgili Karakterlere Etkisi. Ankara Üniversitesi Tarım Bilimleri Dergisi, 10 (3), 342-345.

Güngör, H., Dumlupınar, Z. (2018). Bazı Nohut Çeşit ve Hatlarının Verim ve Verim Unsurları Bakımından Değerlendirilmesi, Derim 35 (2), 194-200.

Kabir, F.A.H.M., Bari, M.N., Karim, M.A., Khaliq, Q.A., Ahmed, J.U. (2009). Effect of Sowing Time and Cultivars on the Growth and Yield of Chickpea Under Rainfed Condition. Bangladesh Journal of Agricultursl Research, 34 (2), 33542.

Karakan Kaya, F. (2014). Bazı Nohut (Cicer arietinum L.) Çeşitlerinin Elazığ Koşullarındaki Verim ve Adaptasyon Yeteneklerinin Belirlenmesi. Bingöl Üniversitesi Fen Bilimleri Enstitüsü Yüksek Lisans Tezi, Bingöl.

Karakullukçu, E., Adak, M.S. (2008). Bazı nohut (Cicer arietinum L.) çeşitlerinin tuza toleranslarının belirlenmesi. Ankara Üniversitesi Tarım Bilimleri Dergisi, 14 (4), 313319.
Karasu, A., Karadoğan, K. (1999). Isparta Koşullarında Bazı Nohut (Cicer arietinum L.) Hat ve Çeşitlerinin Adaptasyonu Üzerinde Bir Araştırma. Türkiye 3. Tarla Bitkileri Kongresi, Adana, 3, 336-341.

Kaya, M., Şanlı, A., Küçükyumuk, Z., Kara, B., Erdal, İ. (2008). Organik Gübre Olarak Kullanılan Şlempenin Nohut (Cicer arietinum L.)'ta Verim ve Bazı Verim Öğeleri Üzerine Etkileri. Süleyman Demirel Üniversitesi, Fen Bilimleri Enstitüsü Dergisi, 11 (3), 212-218.

Kayan, N., Olgun, M., Kutlu, İ., Ayter, N., Gülmezoğlu, N. (2014). Sulanan ve Sulanmayan Koşullarda Yetiştirilen Nohut (Cicer arietinum L.)'un Gelişme Seyrinin Belirlenmesi. Journal of Agricultural Sciences, 14 (4), 3173.

Korbu, L., Tafes, B., Kassa, G., Mola, T., Fikre, A. (2020). Unlocking the Genetic Potential of Chickpea through Improved Crop Management Practices in Ethiopia: A review. Agronomy for Sustainable Development, 40 (13), 1-20.

Özçelik, H., Bozoğlu, H., Pekşen, E., Mut, Z. (2001). Farklı Ekim Zamanı ve Sıklığında Yetiştirilen Bazı Nohut Çeşitlerinin Tane Verimi ve Bazı Tarımsal Özelliklerinin Belirlenmesi. Türkiye 4. Tarla Bitkileri Kongresi, Tekirdağ, 333-338.

Özdemir, S., Engin, M. (1996). İri Taneli Bazı Nohut Çeşitlerinin Çukurova Bölgesinde Stabilite Analizleri. Turkish Journal of Agriculture and Forestry, 20 (2), 157161.

Özdemir, S., Karadavut, U. (2003). Comparison of thePerformance of Autumn and Spring Sowing of Chickpeas in a TemperateRegion. Turkish Journal of Agriculture and Forestry, 27 (6), 345-352.

Özgün, Ö. S., Biçer, B. T., Şakar, D. (2003). Diyarbakır-Bismil Ekolojik Koşullarında Nohutta Farklı Ekim Zamanlarının Verim ve Verim Unsurlarına Etkilerinin Belirlenmesi Üzerine Bir Araştırma. Türkiye 5. Tarla Bitkileri Kongresi, Diyarbakır, 13-17 Ekim 2003, 2, 428-431.

Özgün, Ö. S., Biçer, B. T., Şakar, D. (2005). Gökçe Nohut Çeşidinde Farklı Ekim Zamanlarının Bitkisel ve Tarımsal Özelliklere Etkisi. Türkiye 6. Tarla Bitkileri Kongresi, Antalya, p: 279-284.

Partigöç, F., Olgun, M., Yıldırım, T., Kumlay, A. M. (2007). Muş’ta optimum verimi sağlamak amaciyla en uygun münavebe sisteminin ve ekim yönteminin belirlenmesi. Tarla Bitkileri Merkez Araştırma Enstitüsü Dergisi, 16 (1-2), 1120.

Purushothaman, R., Upadhyaya, H. D., Gaur, P. M., Gowda, C. L.L., Krishnamurthy, L. (2014). Kabuli and desi chickpeas differ in their requirement for reproductive duration. Field Crops Research, 163, 24-31.

Ray, K., Singh, D., Laljat, B. (2017). Effect of Sowing Time and Seed Rate On Growth and Yield of ChickpeaCultivars. Advance Research Journal of Crop Improvement, 8 (1), 116.

Rehman, H., Qamar, R., Rehman, A., Ahmad, F., Qamar, J., Sagiqib, M., Nawaz, S. (2015). Effect of DifferentSowingDates on Growth and GrainYield of Chickpea (CicerarietinumL.) Cultivars Under AgroEnvironment of Taluka Dokri Sindh, Pakistan. American Journal of Experimental Agriculture, 8 (1), 46-53.

Rezaei, F. (2012). Nohut (Cicer arietinum L.)'ta Tohuma Ön Uygulamanın İlk Gelisme, Nodülasyon ve Tane Verimi Üzerine Etkileri. Ankara Üniversitesi Fen Bilimleri Enstitüsü, Basılmamış Doktora Tezi, Ankara. 
Salih, R.H., Abdullah, S.A., Mohammed, B.I. (2018). Effect of Sowing Dates and Two Chickpea Cultivars on Some Growth Parameters and Yield. ZANCO Journal of Pure and Applied Sciences, 30 (4), 49-57.

Sar1, M., Adak, M. S. (1998). Nohut (Cicer arietinum L.)'ta Farklı Ekim Zamanlarının Bazı Bitki Özellikleri ve Verime Etkileri. Tarla Bitkileri Merkez Araştırma Enstitüsü Dergisi, 7 (2), 57-64.

Sekhar, R., Kumar, P.B.P., Rao, K.T. (2015). Performance of ChickpeaVarieties Under DifferentDates of Sowing in High Altiude Zone of AndhraPradesh, India. International Journal Current Microbiology and AppliedScience, 4 (8), 329-332.

Sikdar, S., Abuyusuf, M., Ahmed, S., Tazmin, M. F. (2015). Variety and Sowing Time on theGrowth and yield of Chickpea (Cicer arietinum L.) in SouthernRegion of Bangladesh. International Journal of Research in Agricultural Sciences, 3 (6), 6920-6945.

Sozen, O., Karadavut, O. (2018). Correlation and Path Analysis for Yield Performance and Yield Components of Chickpea (Cicer arietinum L.) Genotypes Cultivated in Central Anatolia. Pakistan Journal of Botany, 50 (2), 625-633.

Topalak, C., Ceyhan, E. (2015). Nohutta Farklı Ekim Zamanlarının Tane Verimi ve Bazı Tarımsal Özellikler Üzerine Etkileri. Selçuk Üniversitesi Tarım Bilimleri Dergisi, 2 (2), 128-135.

TUİK. 2018. Tarım İstatiskikleri, Ankara.

Türk, Z., Koç, M. (2003). Diyarbakır Ekolojik Koşullarına Uygun Yüksek Verimli, Nohut (Cicer arietinum L.) Çeşit/Hatlarının Belirlenmesi ÜzerineBir Araştırma. Türkiye 5. Tarla Bitkileri Kongresi, 13-17 Ekim 2003, Diyarbakır, s: 382-386.

Türk, Z., Polat, T. (2019). Diyarbakır Ekolojik Koşullarında Farklı Ekim Zamanı ve Ekim Sıklığının Nohut (Cicer arietinum L.)'un Bazı Tarımsal Özelliklerine Etkisi. Türkiye Tarımsal Araştırmalar Dergisi, 6 (1), 20-31.
Uçar, Ö., Soysal, S., Erman, M. (2020). Farklı Leonardit Dozlarının Nohut (Cicer arietinumL.)'un Verim ve Bazı Verim Özelliklerine Etkileri. Avrupa Bilim ve Teknoloji Dergisi, (20), 917-921.

Uzun, A., Özçelik, H., Yılmaz, S. (2012). Seçilmiş Bazı Nohut (Cicer arietinum L.) Hatlarının Agronomik ve Kalite Özellikleri Bakımından Değerlendirilmesi. Akademik Ziraat Dergisi, 1 (1), 29-36.

Üstün, A., Gülümser, A. (2003). Karadeniz Bölgesinde Nohuta Uygun Ekim Zamanının Belirlenmesi Çalışmaları. Türkiye 5. Tarla Bitkileri Kongresi, Diyarbakır, s: 110-120.

Varoğlu, H., Abak, K. (2019). Effect of SowingDates on Yield and QualityCharacteristics of ChickpeaVarieties under Mediterranean Climate Conditions. Legume Research, 42 (3), 360-364.

Yalçın, F., Mut, Z., ErbasKose, O. D. (2018). Afyonkarahisar ve Yozgat Koşullarında Yüksek Verim Sağlayacak Uygun Nohut (Cicer arietinum L.) Çeşitlerinin Belirlenmesi. Gaziosmanpaşa Üniversitesi Ziraat Fakültesi Dergisi, 35 (1), 46-59.

Yiğitoğlu, D., Anlarsal, A. E. (2012). Kahramanmaraş Koşullarında Farklı Bitki Sıklıklarının Kışlık ve Yazlık Ekilen Bazı Nohut Çeşitlerinde (Cicer arietinum L.) Verim ve Verim ile İlgili Özelliklere Etkisi. Çukurova Üniversitesi Fen ve Mühendislik Bilimleri Dergisi, 27 (2), 11-20.

Yolcu, R, (2008). Diyarbakır Ekolojik Koşullarında Farklı Gelişme Dönemlerinde Sulanan Nohudun (Cicer arietinum L.) Sulama Suyu Gereksinimi ve Su Tüketimi Üzerine Bir Araştırma. Çukurova Üniversitesi Fen Bilimleri Enstitüsü, Basılmamış Yüksek Lisans Tezi, Tarla Bitkileri Anabilim Dali.

Yücel, D. (2020). Genotypic and Phenotypic Variability for Yield and its Components in Normal and Late Sown Chickpea (Cicer arietinum L.). Legume Research, 43, 18-24. 